Article

\title{
Formation of Anticorrosive Film for Suppressing Pitting Corrosion on Al-Mg-Si Alloy by Steam Coating
}

\author{
Ai Serizawa ${ }^{1, *}$, Takuhiro Oda ${ }^{1}$, Kohei Watanabe ${ }^{1}$, Kotaro Mori ${ }^{2}$, Tetsuya Yokomizo ${ }^{2}$ and \\ Takahiro Ishizaki ${ }^{1}$ \\ 1 Department of Materials Science and Engineering, Shibaura Institute of Technology, Tokyo 135-8548, Japan; \\ ac14017@shibaura-it.ac.jp (T.O.); ac14096@shibaura-it.ac.jp (K.W.); ishizaki@shibaura-it.ac.jp (T.I.) \\ 2 Graduate School of Engineering and Science, Shibaura Institute of Technology, Tokyo 135-8548, Japan; \\ mb17037@shibaura-it.ac.jp (K.M.); mb16039@shibaura-it.ac.jp (T.Y.) \\ * Correspondence: serizawa@shibaura-it.ac.jp; Tel.: +81-3-5859-8111
}

Received: 28 November 2017; Accepted: 29 December 2017; Published: 4 January 2018

\begin{abstract}
Al alloys offer excellent physical and mechanical properties, such as a low density, high specific strength, and good ductility. However, their low corrosion resistance has restricted their application in corrosive environments. There is a need, therefore, for a novel coating technology that is capable of improving the corrosion resistance of $\mathrm{Al}$ alloys. In the present study, we examined a steam-based method of forming a corrosion-resistant film on Al alloys. Al-Mg-Si alloy was used as the substrate. The cleaned substrates were set in an autoclave with ultrapure water as the steam source and processed using different temperatures and holding times, resulting in the formation of anticorrosive films on the alloy. FE-SEM images of the film surfaces showed that plate-like nanocrystals were densely formed over the entire surface. XRD patterns indicated that the film was composed mainly of $\mathrm{AlOOH}$ crystals. The potentiodynamic polarization curves revealed that the corrosion current density of the film-coated substrates significantly decreased, and that the pitting corrosion was completely suppressed, indicating that the corrosion resistance of the Al-Mg-Si alloy was improved by the film formed by means of steam coating.
\end{abstract}

Keywords: steam coating; aluminum alloy; corrosion resistance; pitting corrosion; potentiodynamic polarization

\section{Introduction}

Given the lightness of $\mathrm{Al}, \mathrm{Al}$ alloys are frequently used as structural materials. The superior mechanical and physical properties of these alloys make them ideal for use as structural materials. These properties include a high strength-to-weight ratio, good formability, high thermal conductivity, and excellent recyclability. Given these properties, $\mathrm{Al}$ alloys have found numerous applications in a wide range of industries, including automobiles, building, and heat-transfer components.

One series of Al alloys, namely, Al-Mg-Si alloy (AA6000 series aluminum alloy), has been utilized to fabricate lightweight automobile body panels due to its good precipitation-hardening response at the temperature that was used to cure the paint applied to the vehicle (approximately $170-180{ }^{\circ} \mathrm{C}$ ) [1-6]. $\mathrm{Al}-\mathrm{Mg}$-Si alloys are lightweight medium-strength heat-treatable $\mathrm{Al}$ alloys with an excellent combination of cost-effective engineering properties that makes them ideal for a wide range of applications, from the transportation [7,8] and building industries [9] to high-voltage power transmission [10]. Despite their outstanding advantages as structural materials, however, Al-Mg-Si alloys also have some disadvantages. Among these is their inadequate corrosion resistance, which occasionally restricts the environments to which they can be applied. The recent increase in interest in these alloys, particularly 
for automotive panel applications, has led to intense research into means of improving their corrosion resistance through the development of new coating techniques, and thus enables the use of Al-Mg-Si alloys as a structural material.

When $\mathrm{Al}$ alloy surfaces are not protected by anodizing and/or a suitable coating process, they develop a protective layer of aluminum oxide. This natural oxide film is extremely thin (nanometer scale), so may not always be capable of protecting an $\mathrm{Al}$ alloy. The thickness of the oxide depends on the type of the $\mathrm{Al}$ alloy, with the thickness of that which forms on an $\mathrm{Al}-\mathrm{Mg}$-Si alloy being reported to be $3-5 \mathrm{~nm}$ [11]. This is too thin to protect the alloy from corrosion. Given this background, various surface treatments have been developed to improve the corrosion resistance of these alloys. Electroplating [12], anodization [13-15], and chemical conversion treatment [16] are representative surface treatments used industrially for many types of Al alloy. Recently, several new coating techniques have been developed for these alloys, including plasma electrolytic oxidation coating (PEO-coating) although, strictly speaking, this is an anodizing technique [17-19]. A major disadvantage of these methods is that the liquid waste that they produce requires treatment prior to its disposal, and incurs a risk of environmental pollution due to the heavy metal ions that are involved. Therefore, there is a strong demand for an environmentally friendly means of treating $\mathrm{Al}$ alloys.

Steam coating technology was originally developed to improve the corrosion resistance of $\mathrm{Mg}$ alloys [20-22]. Steam coating technology produces a dense film on the surface of a metal using steam, which is produced in a pressure vessel, i.e., an autoclave. The main advantage of steam coating is that it uses only water, dispensing with the need for chemicals, making it an environmentally friendly coating technique. Using this method, protective films can be grown directly on a substrate, such that the film exhibits excellent adhesion to the substrate. Furthermore, the process can be applied to components with complicated shapes and large substrates. Finally, steam coating does not require any pre-treatment. Instead, the metal reacts with the steam to produce a hydroxide layer. The type of metal determines the resulting layer. In the case of AZ31 magnesium alloy, the film which forms on the substrate as a result of the steam coating consists of $\mathrm{Mg}(\mathrm{OH})_{2}$ and $\mathrm{Mg}-\mathrm{Al} \mathrm{LDH} \mathrm{[20,21].} \mathrm{In} \mathrm{contrast,}$ in AZX612 magnesium alloy, $\mathrm{AlOOH}$ is simultaneously formed with the $\mathrm{Mg}(\mathrm{OH})_{2}$ and $\mathrm{Mg}-\mathrm{Al} \mathrm{LDH}$, due to the different compositions of solute elements in the alloy [23]. Thus, it would be a challenge to apply steam coating technology to the creation of a corrosion-resistant film on an $\mathrm{Al}$ alloy.

In the present study, steam coating was applied to an Al-Mg-Si alloy, and the resultant film was characterized and evaluated by electrochemical measurements. In particular, pitting corrosion behavior was investigated because this property of the alloys is particularly significant when they are applied as structural materials. The objective of the present study is to develop a new coating technology that is environmentally friendly, and thus contributes to the creation of a sustainable society.

\section{Materials and Methods}

\subsection{Substrate}

An Al-Mg-Si alloy with a size of $20 \mathrm{~mm} \times 20 \mathrm{~mm}$ was used as the substrate. The chemical composition of the alloy is listed in Table 1. The chemical composition is the same as that of AA6022. The alloy was supplied as 1.0-mm cold-rolled sheets.

Table 1. Chemical composition of alloy used in the present study (wt \%).

\begin{tabular}{ccccccccc}
\hline $\mathbf{M g}$ & $\mathbf{S i}$ & $\mathbf{C u}$ & $\mathbf{M n}$ & $\mathbf{F e}$ & $\mathbf{C r}$ & $\mathbf{Z n}$ & $\mathrm{Ti}$ & $\mathrm{Al}$ \\
\hline 0.59 & 0.96 & 0.01 & 0.05 & 0.18 & 0.04 & 0.01 & 0.02 & Bal. \\
\hline
\end{tabular}

\subsection{Steam Coating}

The substrates were ultrasonically cleaned in absolute ethanol for $10 \mathrm{~min}$. The cleaned specimens were then set in an industrial autoclave. The steam coating was performed using a horizontal autoclave 
made of stainless steel with a volume of $10 \mathrm{~m}^{3}$. The autoclave was a cylindrical with a diameter of $1.5 \mathrm{~m}$ and the length of $2.7 \mathrm{~m}$. Ion-exchanged water was used as the steam source. A flow of temperature-controlled steam between $160{ }^{\circ} \mathrm{C}$ and $180^{\circ} \mathrm{C}$ was introduced into the autoclave. The pressure was also set to $0.6 \mathrm{MPa}$ at $160{ }^{\circ} \mathrm{C}, 0.75 \mathrm{MPa}$ at $170{ }^{\circ} \mathrm{C}$, and $0.95 \mathrm{MPa}$ at $180{ }^{\circ} \mathrm{C}$. The steam coating process was conducted for $0.5-1 \mathrm{~h}$. Once the required holding time had elapsed, the autoclave was allowed to cool naturally to room temperature, resulting in the formation of an anticorrosive film on the $\mathrm{Al}$ alloys. A schematic illustration of the steam coating technology is shown in Figure 1.

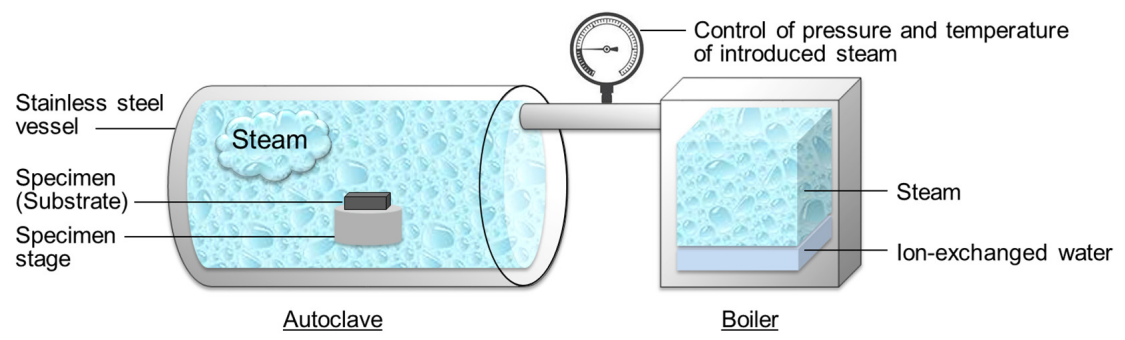

Figure 1. Schematic of proposed steam coating technique.

\subsection{Film Characterizations}

The resultant films were characterized as follows. The surface morphologies of the anticorrosive films on the Al-Mg-Si alloy substrates were observed using a field emission scanning electron microscope (FE-SEM; JSM-7610F, JEOL Ltd., Tokyo, Japan), operating at $15 \mathrm{kV}$. The crystal phase of the obtained film was identified using glancing-angle X-ray diffraction (GAXRD; Ultima IV, Rigaku, Tokyo, Japan), at a glancing angle of $1^{\circ}$ with $\mathrm{Cu} \mathrm{K} \alpha$ radiation $(40 \mathrm{kV}, 40 \mathrm{~mA})$ within a range of $5^{\circ}-80^{\circ}$ and at a scanning rate of $2 \theta=4^{\circ} \mathrm{min}^{-1}$.

The corrosion resistance was estimated by electrochemical measurements. All of the electrochemical measurements were performed using a $5.0 \mathrm{wt} \% \mathrm{NaCl}$ aqueous solution and a computer-controlled potentiostat (VersaSTAT4, Princeton Applied Research). The film-coated Al-Mg-Si alloy and a platinum mesh were used as a working and counter electrode, respectively. Saturated $\mathrm{Ag} / \mathrm{AgCl}$ was used as the reference electrode. The specimens were immersed in a $\mathrm{NaCl}$ solution for $30 \mathrm{~min}$ at room temperature with removing oxygen prior to testing to allow for the system to stabilize, and then potentiodynamic polarization curves were obtained with respect to the open circuit potential (OCP) at a scanning rate of $10 \mathrm{mV} \cdot \mathrm{s}^{-1}$, from $-100 \mathrm{mV}$ to $+800 \mathrm{mV}$. The total exposed surface area was $1 \mathrm{~cm}^{2}$. The corrosion potential, $E_{\text {corr }}$, and corrosion current density, $i_{\text {corr }}$, values were determined from the experimental potentiodynamic curves using the CorrView program to obtain the fitting parameters. An immersion corrosion test was conducted to evaluate the corrosion resistance of the specimens that were subjected to the steam coating. The sample surface, measuring $20 \mathrm{~mm} \times 20 \mathrm{~mm} \times 1.0 \mathrm{~mm}$, was exposed to a $5.0 \mathrm{wt} \% \mathrm{NaCl}$ solution. The remaining surface was sealed with Teflon tape. The temperature of the $\mathrm{NaCl}$ solution was held at $35^{\circ} \mathrm{C}$. The specimens were immersed in the $\mathrm{NaCl}$ solution for up to $48 \mathrm{~h}$. The solution was renewed every $12 \mathrm{~h}$. After the immersion corrosion test, the appearance of the surface was observed, followed by the surface morphologies and the crystal structure was analyzed using FE-SEM and XRD, respectively.

\section{Results}

\subsection{Characterization of Film}

The appearances of the films prepared by steam coating at $160^{\circ} \mathrm{C}, 170{ }^{\circ} \mathrm{C}$, and $180^{\circ} \mathrm{C}$ for $1 \mathrm{~h}$ are shown in Figure 2. When compared to the appearance of the as-received, uncoated material, the surface was uniformly covered with a matt film, which had been successfully formed on the $\mathrm{Al}-\mathrm{Mg}$-Si alloy substrate. In general, if a surface treatment is effective for pure $\mathrm{Al}$, it will often fail to work with $\mathrm{Al}$ alloys, because some components of the $\mathrm{Al}$ alloys suppress the formation of the 
films [24,25]. Non-uniform microstructures, such as the second-phase particles in an aluminum alloy, play a major role in the passivity breakdown and pit morphology of aluminum alloys in seawater [26,27]. In addition, Idrac et al. [28] indicated that non-uniform microstructures in an $\mathrm{Al}-\mathrm{Cu}$ alloy resulted in pitting susceptibility in galvanic corrosion.

The difficulties associated with surface treatment usually depend on the type of the $\mathrm{Al}$ alloy, with multi-component alloys, such as Al-Mg-Si and Al-Zn-Mg, being the most problematic. The film formed on those substrates treated at $180{ }^{\circ} \mathrm{C}$ was much more uniform than that formed at lower temperatures.

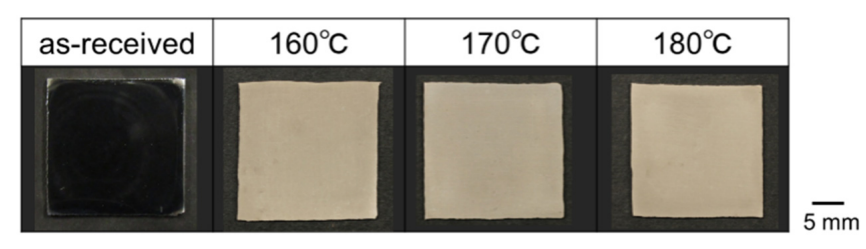

(a)

(b)

(c)

(d)

Figure 2. Appearance of (a) uncoated specimen and specimens subjected to steam coating at (b) $160{ }^{\circ} \mathrm{C}$, (c) $170{ }^{\circ} \mathrm{C}$, and (d) $180{ }^{\circ} \mathrm{C}$ for $1 \mathrm{~h}$.

SEM images showing the surfaces of the specimens subjected to steam coating at $160{ }^{\circ} \mathrm{C}, 170{ }^{\circ} \mathrm{C}$, and $180^{\circ} \mathrm{C}$, for various durations, are shown in Figure 3. Needle or lath-like crystals were clearly observed on the surfaces of all the specimens. The crystals completely covered the surface, and the distribution of the crystal size was small, regardless of the process conditions. The typical length of the crystals was 50-300 nm, while their width was $14-20 \mathrm{~nm}$. Both the length and width increased slightly with the treatment temperature and holding time. A cross-sectional view of the vicinity of the interface between the film and substrate is shown in Figure 4. The film was found to be perfectly dense and the thickness of the film was approximately $1.2 \mu \mathrm{m}$. No minute pores were observed in either the film or the interface. There were no compounds at the interface, suggesting that the adhesion between the film and substrate is superior. Such a dense film should be resistant to corrosion.

Figure 5 shows the XRD profiles of the films prepared at $160-180{ }^{\circ} \mathrm{C}$ for up to $1 \mathrm{~h}$. Several peaks corresponding to aluminum hydroxide, i.e., Boehmite, $\gamma$-AlOOH were observed for all of the specimens. In contrast, the peak corresponding to $\mathrm{AlOOH}$ was not observed for the as-received specimen. Two sets of peaks corresponding to $\mathrm{Mg}_{2} \mathrm{Si}, \mathrm{Al}-\mathrm{Fe}-\mathrm{Si}$ were also observed for all of the specimens, including the as-received specimen. Those compounds could be derived from the substrate, which forms in the alloy prior to the steam coating. All of the films consisted of aluminum hydroxide, regardless of the treatment temperature and duration.

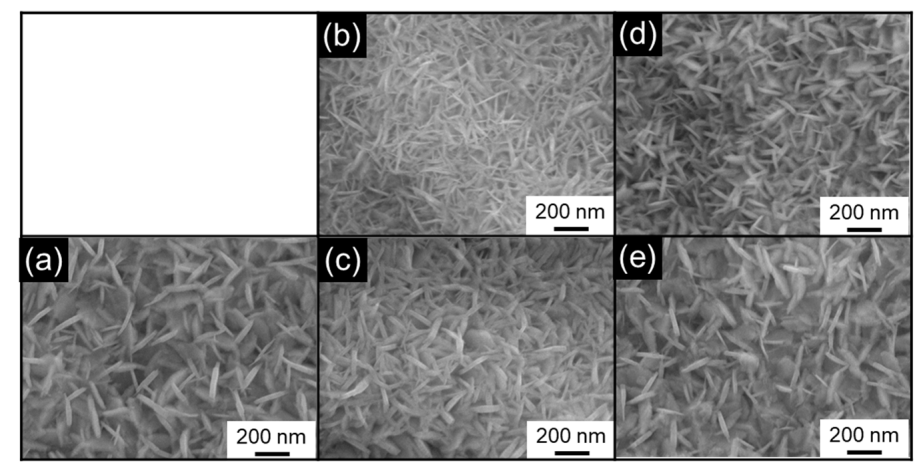

Figure 3. SEM images showing surfaces of specimens subjected to steam coating under different conditions: (a) $160{ }^{\circ} \mathrm{C}$ for $1 \mathrm{~h}$; (b) $170{ }^{\circ} \mathrm{C}$ for $0.5 \mathrm{~h}$; (c) $170{ }^{\circ} \mathrm{C}$ for $1 \mathrm{~h}$; (d) $180{ }^{\circ} \mathrm{C}$ for $0.5 \mathrm{~h}$; (e) $180{ }^{\circ} \mathrm{C}$ for $1 \mathrm{~h}$. 


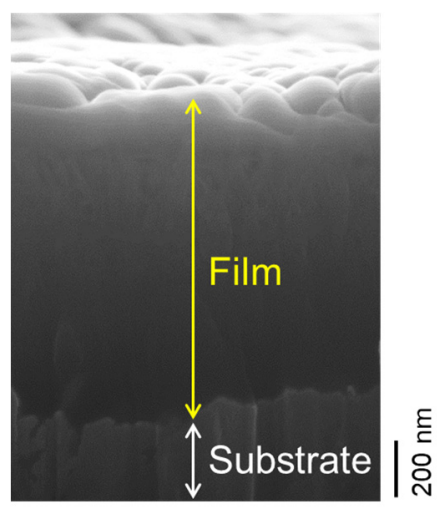

Figure 4. Cross-sectional view of film prepared at $180^{\circ} \mathrm{C}$ for $1 \mathrm{~h}$.

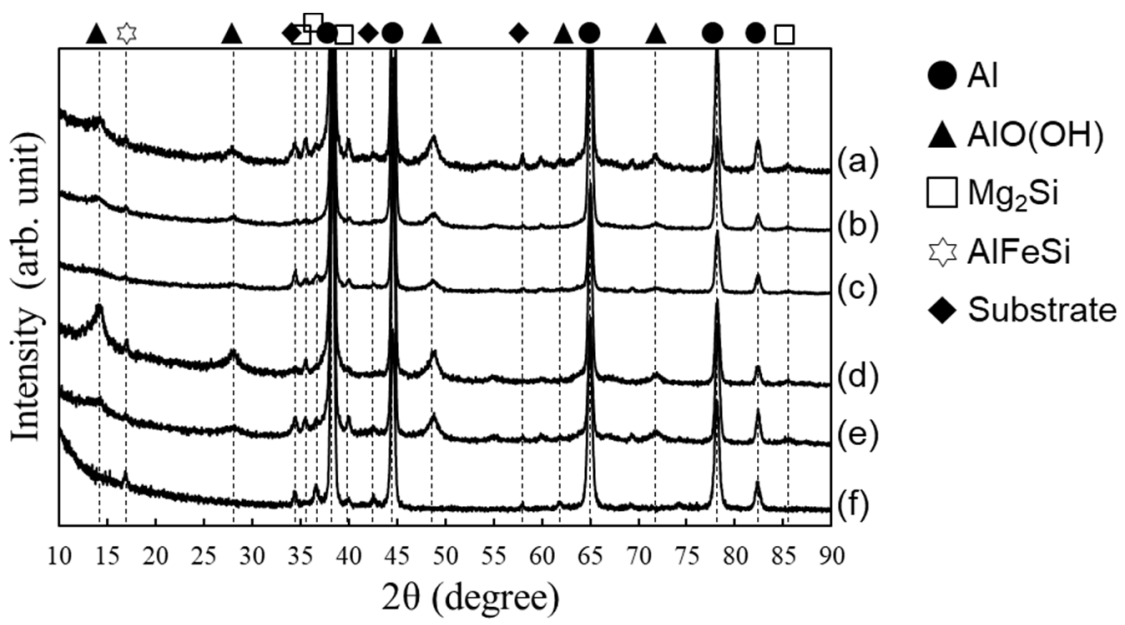

Figure 5. GAXRD profiles of specimens subjected to steam coating at (a) $160{ }^{\circ} \mathrm{C}$ for $1 \mathrm{~h} ;$ (b) $170{ }^{\circ} \mathrm{C}$ for $0.5 \mathrm{~h}$; (c) $170{ }^{\circ} \mathrm{C}$ for $1 \mathrm{~h}$; (d) $180{ }^{\circ} \mathrm{C}$ for $0.5 \mathrm{~h}$; (e) $180{ }^{\circ} \mathrm{C}$ for $1 \mathrm{~h}$; and (f) as-received specimen as a reference.

The thermodynamics of aluminum-water reactions were considered to discuss the chemical reactions that occur during steam coating. The following reactions between the aluminum and water could occur between room temperature and the melting point of aluminum $\left(660^{\circ} \mathrm{C}\right)$ :

$$
\begin{gathered}
2 \mathrm{Al}+6 \mathrm{H}_{2} \mathrm{O}=2 \mathrm{Al}(\mathrm{OH})_{3}+3 \mathrm{H}_{2} \\
2 \mathrm{Al}+4 \mathrm{H}_{2} \mathrm{O}=2 \mathrm{AlO}(\mathrm{OH})+3 \mathrm{H}_{2} \\
2 \mathrm{Al}+3 \mathrm{H}_{2} \mathrm{O}=\mathrm{Al}_{2} \mathrm{O}_{3}+3 \mathrm{H}_{2}
\end{gathered}
$$

The first reaction forms the aluminum hydroxide known as gibbsite $\left(\mathrm{Al}(\mathrm{OH})_{3}\right)$ and hydrogen, the second reaction forms the aluminum hydroxide, known as boehmite $(\mathrm{AlOOH})$ and hydrogen, while the third reaction forms aluminum oxide and hydrogen. All of these reactions are thermodynamically favorable from room temperature to a point beyond the melting point of aluminum. They are all highly exothermic. From room temperature to $280^{\circ} \mathrm{C}$, the $\mathrm{Al}(\mathrm{OH})_{3}$ is the most stable, while $\mathrm{AlOOH}$ is the most stable from $280{ }^{\circ} \mathrm{C}$ to $480{ }^{\circ} \mathrm{C}$. Above $480{ }^{\circ} \mathrm{C}, \mathrm{Al}_{2} \mathrm{O}_{3}$ is the most stable [29]. The steam coating was performed between $160{ }^{\circ} \mathrm{C}$ and $180{ }^{\circ} \mathrm{C}$, which is lower than the temperature at which $\mathrm{AlOOH}$ forms, given the change in the energy required for formation in the pressurized autoclave. The state of the water, including the liquid and gas phases, is summarized in a general pressure-temperature diagram for water. The reaction field is regarded as being a balanced field of subcritical water as the liquid phase and saturated steam as the gas phase. The subcritical 
water exists at temperatures between the atmospheric boiling point and the critical temperature of water $\left(374^{\circ} \mathrm{C}\right)$. Thus, the most significant chemical reaction occurring during the steam coating process was that defined by Equation (2).

The reaction field existing during steam coating is unique, in that two phases, steam and subcritical water coexist. The two phases are gas and liquid. With this unique reaction field, $\mathrm{AlOOH}$ crystals formed. Furthermore, the nucleation frequency of $\mathrm{AlOOH}$ crystals increased as a result of restricting the supply of $\mathrm{OH}^{-}$ions, which is necessary to form $\mathrm{AlOOH}$. Thus, a dense corrosion-resistant film is successfully formed, thus improving the corrosion resistance of the $\mathrm{Al}$ alloys.

\subsection{Evaluation of Corrosion Resistance}

The steam-coated film on the Al-Mg-Si alloy was characterized from the viewpoints of appearance, crystal structure, and surface morphology. The corrosion resistance of the film was evaluated by electrochemical measurements. The following is an example of the evaluation of the corrosion resistance of the film-coated $\mathrm{Al}$ alloys, as determined by electrochemical measurements.

The corrosion resistance of the film formed on Al-Mg-Si was determined from potentiodynamic polarization curve measurements. The potentiodynamic polarization curves of those specimens subjected to steam coating at $160{ }^{\circ} \mathrm{C}$ and $180{ }^{\circ} \mathrm{C}$ for $1 \mathrm{~h}$ are shown in Figure 6 . As a control, the potentiodynamic polarization curve of untreated Al-Mg-Si alloy is also shown in Figure 6a. The corrosion potentials $\left(E_{\text {corr }}\right)$ and corrosion current densities $\left(i_{\text {corr }}\right)$ of the as-received Al-Mg-Si alloy and the samples prepared by steam coating under various conditions, as obtained from the Tafel slopes of the polarization curve, are listed in Table 2 . The $E_{\text {corr }}$ and $i_{\text {corr }}$ values of the sample that were treated at $180{ }^{\circ} \mathrm{C}$ for $1 \mathrm{~h}$ were estimated to be $-0.75 \mathrm{~V}$ and $4.8 \times 10^{-8} \mathrm{~A} / \mathrm{cm}^{2}$, respectively. The corrosion current density value, $i_{\text {corr }}$ of the film-coated Al-Mg-Si alloy decreased by more than one order of magnitude, relative to the uncoated Al-Mg-Si alloy, while the corrosion potential values, $E_{\text {corr }}$, exhibited no obvious differences. Furthermore, pitting corrosion was not observed in the film-coated $\mathrm{Al}-\mathrm{Mg}$-Si alloy only when the steam coating was conducted at the higher temperature, that is, $180{ }^{\circ} \mathrm{C}$. The steam-coated samples of the Al-Mg-Si alloy were found to have a positive potential and a lower current density than the uncoated sample, indicating that the steam-coated sample offered better corrosion resistance. Thus, a novel method of preparing an $\mathrm{AlOOH}$ film on an $\mathrm{Al}$ alloy by steam coating was successfully established. The corrosion resistance of the film-coated Al-Mg-Si alloy was thus superior to that of bare alloy, due to the formation of the composite film by steam coating.

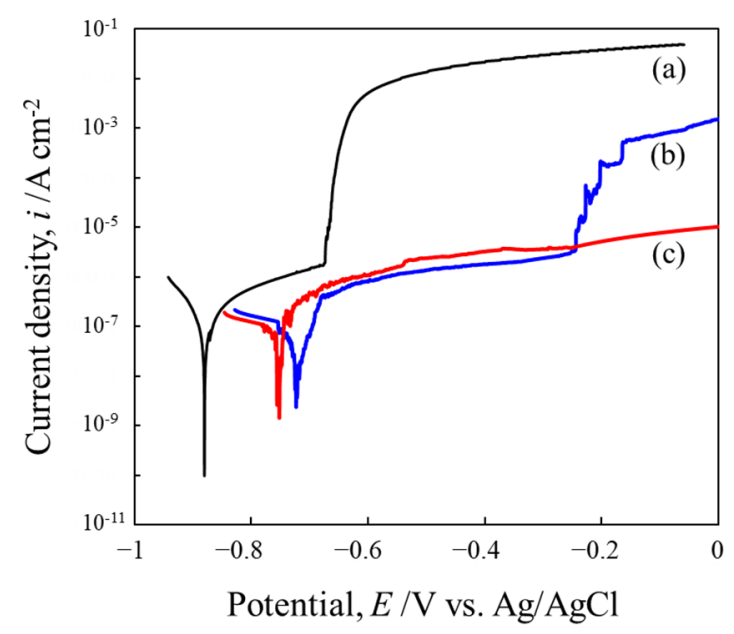

Figure 6. Potentiodynamic polarization curves of (a) as-received specimen and specimens subjected to steam coating at (b) $160^{\circ} \mathrm{C}$ and (c) $180^{\circ} \mathrm{C}$ for $1 \mathrm{~h}$, after immersion in $\mathrm{NaCl}$ solution for $0.5 \mathrm{~h}$. 
Table 2. Fitting results of potentiodynamic polarization curves of as-received and film-coated specimens immersed in $\mathrm{NaCl}$ solution.

\begin{tabular}{ccc}
\hline Specimen & $\boldsymbol{E}_{\text {corr }}(\mathbf{V}$ vs. $\mathbf{A g} / \mathbf{A g C l})$ & $\boldsymbol{i}_{\text {corr }}\left(\mathrm{A} \mathrm{cm}^{-2}\right)$ \\
\hline As-received & -0.88 & $2.6 \times 10^{-7}$ \\
Steam coating $\left(160^{\circ} \mathrm{C}, 1 \mathrm{~h}\right)$ & -0.72 & $8.7 \times 10^{-8}$ \\
Steam coating $\left(180^{\circ} \mathrm{C}, 1 \mathrm{~h}\right)$ & -0.75 & $4.8 \times 10^{-8}$ \\
\hline
\end{tabular}

\subsection{Evaluation of Anticorrosive Film by Immersion Corrosion Test}

An immersion corrosion test was performed to evaluate the pitting corrosion properties of the bare Al-Mg-Si alloy and the film-coated Al-Mg-Si alloy. The appearance of the surfaces of the uncoated specimen and that subjected to steam coating at $180^{\circ} \mathrm{C}$ for $1 \mathrm{~h}$, after an immersion test in salt water for various durations, are shown in Figure 7. Low-magnification and high-magnification SEM images showing the surface morphologies of (a) the uncoated specimen and (b) the specimen subjected to steam coating at $180{ }^{\circ} \mathrm{C}$ for $1 \mathrm{~h}$, after immersion in salt water for various durations, are shown in Figures 8 and 9 , respectively. The appearance of the surface of the specimen that was subjected to steam coating at $180^{\circ} \mathrm{C}$ for $1 \mathrm{~h}$ exhibited no damage at all, even after saltwater immersion for $48 \mathrm{~h}$. In contrast, considerable pitting corrosion was observed on the as-received specimen, even after only $6 \mathrm{~h}$ of saltwater immersion. The natural oxide film had failed, revealing the bare $\mathrm{Al}$ substrate, as shown in Figure 8a. The number of cracks increased with the immersion time. At the same time, the width of the cracks increased with the immersion time in the case of the uncoated specimen. On the other hand, the surface of the specimen with the anticorrosive film remained totally covered with $\mathrm{AlOOH}$ nanocrystals, as shown in Figure 8b, while the size of the $\mathrm{AlOOH}$ nanocrystals was quite uniform, as shown in Figure 9b.

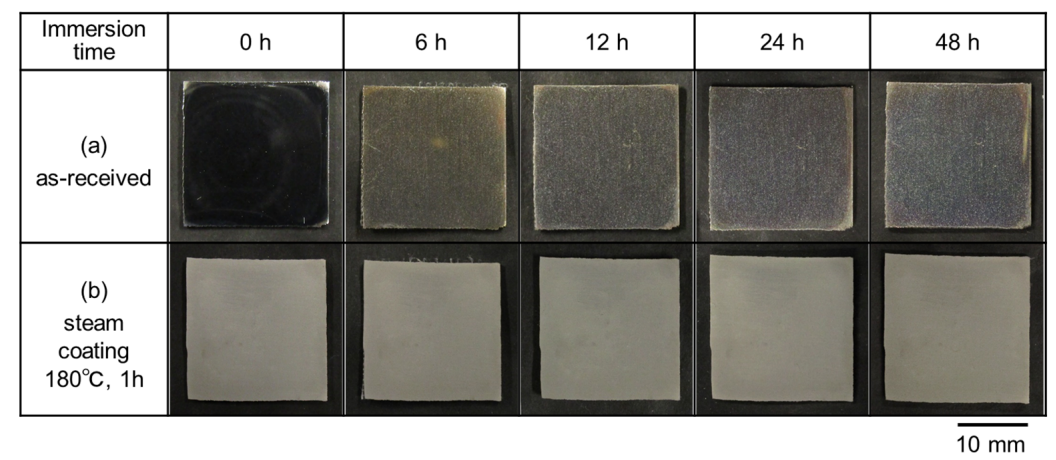

Figure 7. Appearance of surface of (a) uncoated specimen and (b) specimen subjected to steam coating at $180^{\circ} \mathrm{C}$ for $1 \mathrm{~h}$, after immersion corrosion test in $\mathrm{NaCl}$ solution for up to $48 \mathrm{~h}$.

\begin{tabular}{|c|c|c|c|c|c|}
\hline $\begin{array}{c}\text { Immersion } \\
\text { time }\end{array}$ & $0 \mathrm{~h}$ & $6 \mathrm{~h}$ & $12 \mathrm{~h}$ & $24 \mathrm{~h}$ & $48 \mathrm{~h}$ \\
\hline $\begin{array}{c}\text { (a) } \\
\text { as-received }\end{array}$ & & & & & \\
\hline $\begin{array}{c}\text { (b) } \\
\text { steam } \\
\text { coating } \\
180^{\circ} \mathrm{C}, 1 \mathrm{~h}\end{array}$ & & 5 & 5 & & \\
\hline
\end{tabular}

Figure 8. Low-magnification SEM images showing surface morphology of (a) uncoated specimen and (b) specimen subjected to steam coating at $180{ }^{\circ} \mathrm{C}$ for $1 \mathrm{~h}$, after saltwater immersion for up to $48 \mathrm{~h}$. 


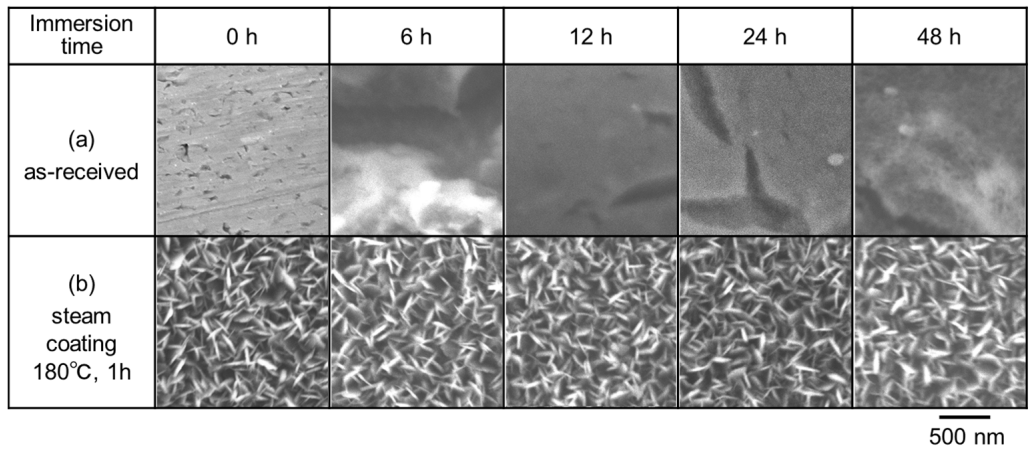

Figure 9. High-magnification SEM images showing surface morphologies of (a) uncoated specimen and (b) specimen subjected to steam coating at $180{ }^{\circ} \mathrm{C}$ for $1 \mathrm{~h}$, after saltwater immersion for up to $48 \mathrm{~h}$.

The GAXRD profiles of the uncoated specimen and the specimen subjected to steam coating at $180{ }^{\circ} \mathrm{C}$ for $1 \mathrm{~h}$ are shown in Figure 10. Figure 10a,c are the profiles of the specimens before the immersion corrosion test, while Figure $10 \mathrm{~b}, \mathrm{~d}$ are the profiles for the specimens after the saltwater immersion test at $35{ }^{\circ} \mathrm{C}$ for $48 \mathrm{~h}$. No significant change was observed in either the uncoated or film-coated Al-Mg-Si alloys. The oxidation of the aluminum produces $\mathrm{Al}(\mathrm{OH})_{3}$, which is insoluble in water and precipitates as a white gel [30]. In the XRD profiles for the specimen after the immersion corrosion test, the reflection corresponding to $\mathrm{Al}(\mathrm{OH})_{3}$ was not observed for either the uncoated or film-coated Al-Mg-Si alloys.

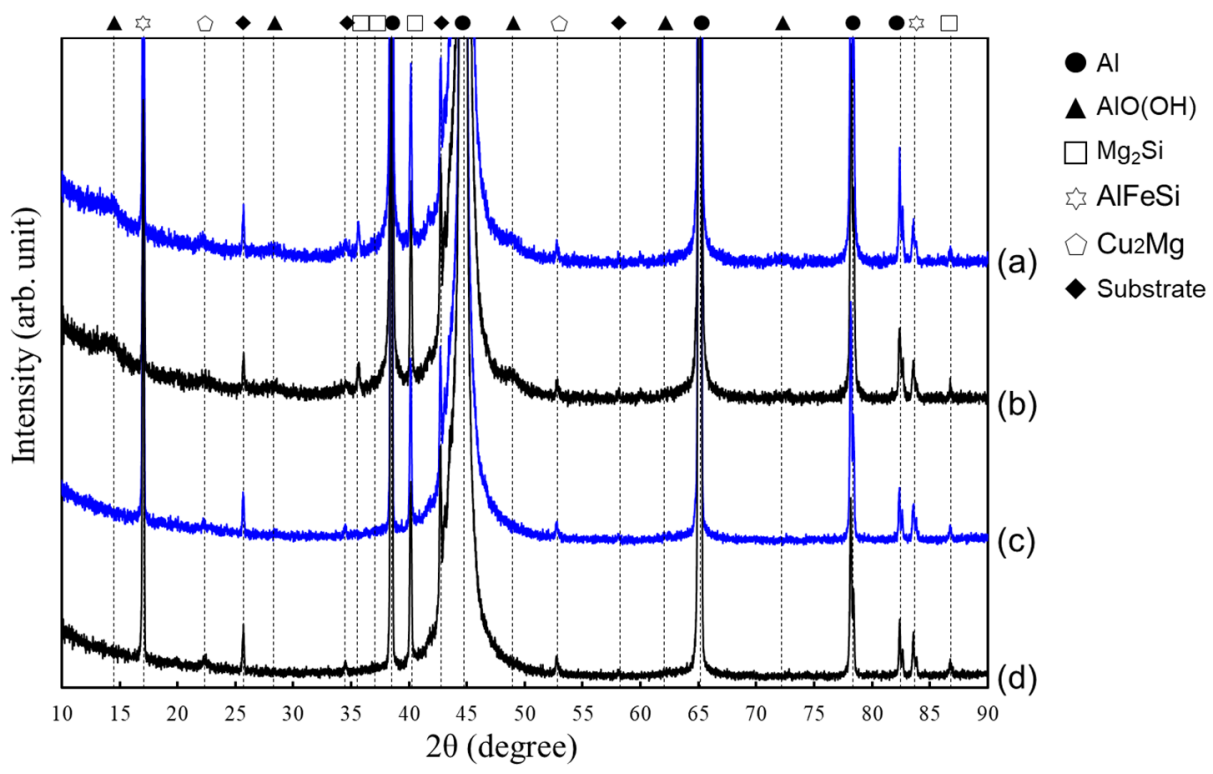

Figure 10. Glancing-angle $X$-ray diffraction (GAXRD) profiles of $(\mathbf{a}, \mathbf{b})$ uncoated specimen and (c,d) specimen subjected to steam coating at $180{ }^{\circ} \mathrm{C}$ for $1 \mathrm{~h}$. (a,c) before the saltwater immersion test and $(\mathbf{b}, \mathbf{d})$ after the saltwater immersion test at $35^{\circ} \mathrm{C}$ for $48 \mathrm{~h}$.

The polarization curves of the as-received specimen and that subjected to steam coating at $180{ }^{\circ} \mathrm{C}$ for $1 \mathrm{~h}$ after saltwater immersion for $48 \mathrm{~h}$ are shown in Figure 11a. The appearance of the surface of the as-received specimen and that subjected to steam coating at $180^{\circ} \mathrm{C}$ for $1 \mathrm{~h}$, both before and after the saltwater immersion test for $48 \mathrm{~h}$, are also shown in Figure 11b. The microcorrosion was observed at a potential of $-0.99 \mathrm{~V}$. The pitting corrosion continued to be suppressed by the steam coating even after saltwater immersion for $48 \mathrm{~h}$. On the other hand, the dissolution of aluminum was frequently observed on the anode branch in the case of the uncoated specimen. The Tafel slopes ( $b_{\mathrm{a}}$ : anodic Tafel constant; $b_{\mathrm{c}}$ : cathodic Tafel constant) obtained from the polarization curve for both specimens are shown in 
Table 3. The $E_{\text {corr }}$ and $i_{\text {corr }}$ values for the anticorrosive-film-coated Al-Mg-Si alloy were estimated to be $-1.16 \mathrm{~V}$ vs. $\mathrm{Ag} / \mathrm{AgCl}$ and $8.2 \times 10^{-8} \mathrm{~A} \mathrm{~cm}^{-2}$, respectively. These results were interpreted as implying, in the case of the uncoated specimen, that the dominant reaction was the dissolution of the aluminum because the pitting already existed due to the saltwater immersion for $48 \mathrm{~h}$. On the other hand, in the case of the film-coated specimen, the film prevents the dissolution of the aluminum when compared with the bare specimen, such that a corrosion reaction is suppressed by the applying the steam coating for the alloy.

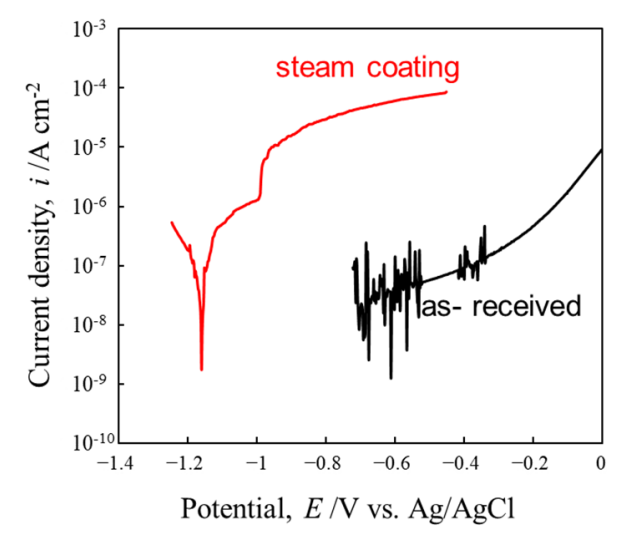

(a)

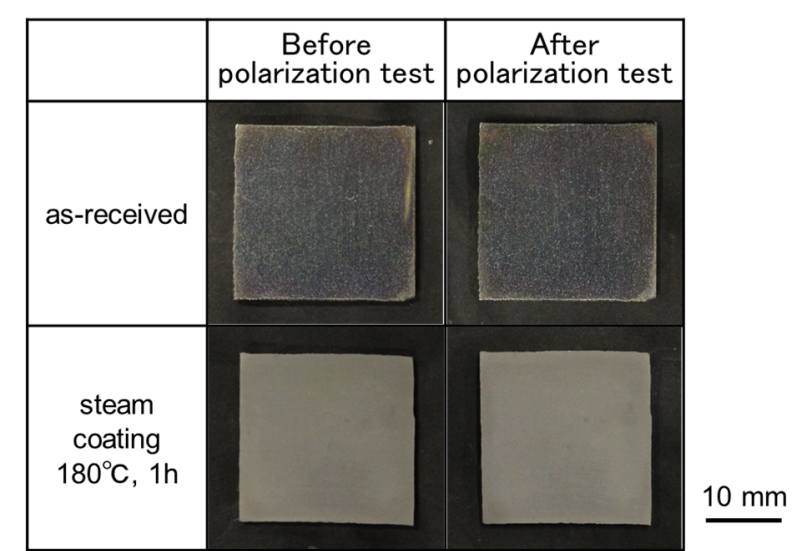

(b)

Figure 11. (a) Polarization curves of as-received specimen and specimen subjected to steam coating at $180{ }^{\circ} \mathrm{C}$ for $1 \mathrm{~h}$ after the saltwater immersion for $48 \mathrm{~h}$. (b) Appearance of surface of as-received specimen and that subjected to steam coating at $180^{\circ} \mathrm{C}$ for $1 \mathrm{~h}$, before and after immersion corrosion test in an $\mathrm{NaCl}$ solution for $48 \mathrm{~h}$.

Table 3. Tafel plot measurement of potentiodynamic polarization curves of as-received and film-coated specimens after immersion in $\mathrm{NaCl}$ solution for $48 \mathrm{~h}$.

\begin{tabular}{ccccc}
\hline Specimen & $E_{\text {corr }}(\mathrm{V}$ vs. $\mathbf{A g} / \mathrm{AgCl})$ & $\boldsymbol{i}_{\text {corr }}\left(\mathrm{A} \mathrm{cm}^{-2}\right)$ & $\boldsymbol{b}_{\mathbf{a}}(\mathrm{V} / \mathrm{Decade})$ & $\boldsymbol{b}_{\mathrm{c}}(\mathrm{V} /$ Decade $)$ \\
\hline Steam coating $\left(180^{\circ} \mathrm{C}, 1 \mathrm{~h}\right)$ & -1.16 & $8.2 \times 10^{-8}$ & 0.069 & 0.104 \\
\hline
\end{tabular}

\section{Conclusions}

The preparation of a corrosion-resistant $\mathrm{AlOOH}$ film on $\mathrm{Al}$ alloys was considered. A steam-coating technology was successfully established for preparing an anticorrosive film on Al-Mg-Si alloys. The film prepared on these alloys consisted mainly of aluminum hydroxide, $\mathrm{AlOOH}$. The potentiodynamic polarization curves of the film-coated and uncoated Al-Mg-Si alloy, after immersion in a $5 \mathrm{wt} \% \mathrm{NaCl}$ aqueous solution for $1 \mathrm{~h}$, revealed that the corrosion current density values, $i_{\text {corr }}$, of the film-coated Al-Mg-Si alloy decreased by approximately one fifth relative to the uncoated Al-Mg-Si alloy. The corrosion current density values, $i_{\text {corr }}$, of the film-coated Al-Mg-Si alloy changed with the steam-coating conditions. In contrast, the corrosion potential values, $E_{\mathrm{corr}}$, exhibited no obvious differences. Furthermore, no pitting corrosion occurred in the film-coated $\mathrm{Al}-\mathrm{Mg}-\mathrm{Si}$ alloy. Thus, a novel means of preparing an $\mathrm{AlOOH}$ film on an $\mathrm{Al}$ alloy by steam coating was successfully established. The corrosion resistance of the film-coated Al-Mg-Si alloy was improved when compared to that of the bare alloy due to the formation of the $\mathrm{AlOOH}$-based film via steam coating. Even after immersion in a $\mathrm{NaCl}$ solution for $48 \mathrm{~h}$, the pitting corrosion did not occur on the $\mathrm{Al}-\mathrm{Mg}-\mathrm{Si}$ alloy that had been film coated using the steam coating method. The improvement in the corrosion resistance of the film-coated Al-Mg-Si alloy was considered to be due to the formation of a dense film without a release of the anticorrosive film from the substrate. Surface modification by controlling the chemical reaction during the steam process improved the corrosion resistance of the Al-Mg-Si alloy 
and also suppressed the pitting corrosion. This would enable the wider application of the alloy in the automotive, building, power transmission, and heat transfer industries.

Acknowledgments: This research was supported by the Japan Science and Technology Agency (JST) under Industry-Academia Collaborative R\&D Program "Heterogeneous Structure Control: Towards Innovative Development of Metallic Structural Materials" (No. 20100120), a Grant-in-Aid for Young Scientists (B) (No. 15K18237) from the Japan Society for the Promotion of Science and Research grant program for younger professors from JGC-S SCHOLARSHIP FOUNDATION (No. 1622).

Author Contributions: Ai Serizawa and Takahiro Ishizaki conceived and designed the experiments; Ai Serizawa and Takahiro Ishizaki manufactured the steam-coating specimens; Takuhiro Oda, Kohei Watanabe, and Kotaro Mori performed the experiments for evaluating the corrosion resistance; Tetsuya Yokomizo performed the structural analysis of the specimens; Ai Serizawa wrote the paper.

Conflicts of Interest: The authors declare no conflict of interest.

\section{References}

1. Dutta, I.; Allen, S.M. A calorimetric study of precipitation in commercial aluminium alloy 6061. J. Mater. Sci. Lett. 1991, 10, 323-326. [CrossRef]

2. Edwards, G.A.; Stiller, K.; Dunlop, G.L.; Couper, M.J. The precipitation sequence in Al-Mg-Si alloys. Acta Mater. 1998, 46, 3893-3904. [CrossRef]

3. Murayama, M.; Hono, K. Pre-precipitate clusters and precipitation processes in Al-Mg-Si alloy. Acta Mater. 1999, 47, 1537-1548. [CrossRef]

4. Esmaeili, S.; Wang, X.; Lloyd, D.J.; Poole, W.J. On the precipitation-hardening behavior of the Al-Mg-Si-Cu alloy AA6111. Metall. Mater. Trans. A 2003, 34, 751-763. [CrossRef]

5. Serizawa, A.; Hirosawa, S.; Sato, T. Three-dimensional atom probe characterization of nanoclusters responsible for multistep aging behavior of an Al-Mg-Si alloy. Metall. Mater. Trans. A 2008, 39, $243-251$. [CrossRef]

6. Serizawa, A.; Sato, T.; Poole, W.J. The characterization of dislocation-nanocluster interactions in Al-Mg-Si(-Cu/Ag) alloys. Philos. Mag. Lett. 2010, 90, 279-287. [CrossRef]

7. Lloyd, D.J. Recent developments in controlling the architecture for property optimization in Al-based materials. Scr. Mater. 2013, 68, 13-16. [CrossRef]

8. Serizawa, A.; Sato, T.; Miller, M.K. Effect of cold rolling on the formation and distribution of nanoclusters during pre-aging in an Al-Mg-Si alloy. Mater. Sci. Eng. A 2013, 561, 492-497. [CrossRef]

9. Zhang, X.H.; Su, G.C.; Ju, C.W.; Wang, W.C.; Yan, W.L. Effect of modification treatment on the microstructure and mechanical properties of Al-0.35\%Mg-7.0\%Si cast alloy. Mater. Des. 2010, 31, 4408-4413. [CrossRef]

10. Karabay, S. Modification of AA-6201 alloy for manufacturing of high conductivity and extra high conductivity wires with property of high tensile stress after artificial aging heat treatment for all-aluminium alloy conductors. Mater. Des. 2006, 27, 821-832. [CrossRef]

11. Evertsson, J.; Bertram, F.; Zhang, F.; Rullik, L.; Merte, L.R.; Shipilin, M.; Soldemo, M.; Ahmadi, S.; Vinogradov, N.; Carlà, F.; et al. The thickness of native oxides on aluminum alloys and single crystals. Appl. Surf. Sci. 2015, 349, 826-832. [CrossRef]

12. Prataap, R.K.V.; Mohan, S. Electrodeposition of Ni-La $\mathrm{O}_{3}$ composite on AA6061 alloy and its enhanced hardness, corrosion resistance and thermal stability. Surf. Coat. Technol. 2017, 324, 471-477. [CrossRef]

13. Schneider, M.; Liebmann, T.; Langklotz, U.; Michaelis, A. Microelectrochemical investigation of anodic oxide formation on the aluminum alloy AA2024. Electrochim. Acta 2017, 249, 198-205. [CrossRef]

14. Chung, C.K.; Tsai, C.H.; Hsu, C.R.; Kuo, E.H.; Chen, Y.; Chung, I.C. Impurity and temperature enhanced growth behaviour of anodic aluminium oxide from AA5052 Al-Mg alloy using hybrid pulse anodization at room temperature. Corros. Sci. 2017, 125, 40-47. [CrossRef]

15. Dejun, K.; Wang, J. Salt spray corrosion and electrochemical corrosion properties of anodic oxide film on 7475 aluminum alloy. J. Alloys Compd. 2015, 632, 286-290. [CrossRef]

16. Viroulaud, R.; Światowska, J.; Seyeux, A.; Zanna, S.; Tardelli, J.; Marcus, P. Influence of surface pretreatments on the quality of trivalent chromium process coatings on aluminum alloy. Appl. Surf. Sci. 2017, 423, 927-938. [CrossRef] 
17. Serdechnova, M.; Mohedano, M.; Bouali, A.C.; Höche, D.; Kuznetsov, B.; Karpushenkov, S.; Blawert, C.; Zheludkevich, M.L. Role of phase composition of PEO coatings on AA2024 for in-situ LDH growth. Coatings 2017, 7, 190. [CrossRef]

18. Gnedenkov, S.V.; Sinebryukhov, S.L.; Egorkin, V.S.; Vyaliy, I.E. Wettability and electrochemical properties of the highly hydrophobic coatings on PEO-pretreated aluminum alloy. Surf. Coat. Technol. 2016, 307, 1241-1248. [CrossRef]

19. Egorkina, V.S.; Gnedenkova, S.V.; Sinebryukhova, S.L.; Vyaliya, I.E.; Gnedenkova, A.S.; Chizhikov, R.G. Increasing thickness and protective properties of PEO-coatings on aluminum alloy. Surf. Coat. Technol. 2018, 334, 29-42. [CrossRef]

20. Ishizaki, T.; Chiba, S.; Suzuki, H. In situ formation of anticorrosive $\mathrm{Mg}-\mathrm{Al}$ layered double hydroxide-containing magnesium hydroxide film on magnesium alloy by steam coating. ECS Electrochem. Lett. 2013, 2, C15-C17. [CrossRef]

21. Ishizaki, T.; Chiba, S.; Watanabe, K.; Suzuki, H. Corrosion resistance of Mg-Al layered double hydroxide container-containing magnesium hydroxide films formed directly on magnesium alloy by chemical-free steam coating. J. Mater. Chem. A 2013, 1, 8968-8977. [CrossRef]

22. Ishizaki, T.; Kamiyama, N.; Watanabe, K.; Serizawa, A. Corrosion resistance of $\mathrm{Mg}(\mathrm{OH})_{2} / \mathrm{Mg}-\mathrm{Al}$ layered double hydroxide composite film formed directly on combustion-resistant magnesium alloy AMCa602 by steam coating. Corros. Sci. 2015, 92, 76-84. [CrossRef]

23. Nakamura, K.; Tsunakawa, M.; Shimada, Y.; Serizawa, A.; Ishizaki, T. Formation mechanism of Mg-Al layered double hydroxide-containing magnesium hydroxide films prepared on Ca-added flame-resistant magnesium alloy by steam coating. Surf. Coat. Technol. 2017, 328, 436-443. [CrossRef]

24. Chiu, L.-H.; Tsai, C.-Y.; Chen, K.-H.; Hu, C.-J.; Chang, H. Effect of coarse second-phase particles on galvanic corrosion of anodized 6061 aluminum alloy coupled with C1100 copper. Int. J. Electrochem. Sci. 2015, 10, 6572-6585.

25. Huang, Y.-S.; Shih, T.-S.; Wu, C.-E. Electrochemical behavior of anodized AA6063-T6 alloys affected by matrix structures. Appl. Surf. Sci. 2013, 264, 410-418. [CrossRef]

26. Ezuber, H.; El-Houd, A.; El-Shawesh, F. A study on the corrosion behavior of aluminum alloys in seawater. Mater. Des. 2008, 29, 801-805. [CrossRef]

27. Lacroix, L.; Blanc, C.; Pebere, N.; Thompson, G.E.; Tribollet, B.; Vivier, V. Simulating the galvanic coupling between $\mathrm{S}-\mathrm{Al}_{2} \mathrm{CuMg}$ phase particles and the matrix of 2024 aerospace aluminium alloy. Corros. Sci. 2012, 64, 213-221. [CrossRef]

28. Idrac, J.; Mankowski, G.; Thompson, G.; Skeldon, P.; Kihn, Y.; Blanc, C. Galvanic corrosion of aluminium-copper model alloys. Electrochim. Acta 2007, 52, 7626-7633. [CrossRef]

29. Digne, M.; Sautet, P.; Raybaud, P.; Toulhoat, H.; Artacho, E. Structure and stability of aluminum hydroxides: A theoretical study. J. Phys. Chem. B 2002, 106, 5155-5162. [CrossRef]

30. Vargel, C.; Jacques, M.; Schmidt, M.P. The Corrosion Behaviour of Aluminium Alloys. In Corrosion of Aluminium; Vargel, C., Ed.; Elsevier Science: Amsterdam, The Netherlands, 2004; pp. 211-230.

(c) 2018 by the authors. Licensee MDPI, Basel, Switzerland. This article is an open access article distributed under the terms and conditions of the Creative Commons Attribution (CC BY) license (http://creativecommons.org/licenses/by/4.0/). 